\title{
The role of mean platelet volume, platelet distribution width and platelet / lymphocyte ratio in development of cerebral venous thrombosis
}

\section{Ortalama platelet hacmi, platelet dağılım genişliği ve platelet/lenfosit oranının serebral venöz tromboz gelişimindeki rolü}

\author{
Aslı Bolayır ${ }^{1}$, Şeydla Figüll Gökçe $e^{1}$
}

Cumhuriyet Üniversitesi Uygulama Hastanesi, Nöroloji Anabilim Dalı, Sivas, Türkiye

Corresponding author: Aslı Bolayır, Cumhuriyet Üniversitesi Uygulama Hastanesi, Nöroloji Anabilim Dalı, Sivas, Türkiye

E-mail: asliarslanturk@gmail.com

Received/Accepted: May 12, 2017 / September 27, 2017

Conflict of interest: There is not a conflict of interest.

\section{SUMMARY}

Objective: Mean platelet volume (MPV) and platelet distribution width (PDW) are parameters that indicate platelet volume. It is assumed that large platelets are enzymatically and metabolically more active than small platelets. The relationship between elevated MPV and PDW values and arterial thrombosis has been demonstrated, but their roles in venous thrombosis are not fully understood. While the platelet / lymphocyte ratio (PLR), which is considered to be an inflammatory indicator, is known to be associated with many diseases, there are only a few studies in venous thrombosis. For this reason, our aim in this study is to establish the relationship between MPV, PDW and PLR values and cerebral venous sinus thrombosis (CVST).

Method: Our study included 54 patients who were diagnosed with CVST in our clinic between January 2008 and September 2016, and 50 controls with similar age and sex. The patients and control groups were compared in terms of MPV, PDW and PLR values. In addition, the patient group was divided into two groups, according to parenchymal brain lesions, and the effect of MPV, PDW, and PLR on prognosis was also assessed.

Results: While the MPV, PDW and PLR values were higher in the patient group compared to the controls, there was no significant difference between patients with and without parenchymal lesions. In addition, as MPV and PDW values for CVST development were determined as significant independent variables, optimal cut-off values were identified 8.85 for MPV, 15.75 for PDW and 168.53 for PLR in ROC analysis.

Conclusions: As a result, MPV, PDW and PLR values were higher in patients with SVST than controls, however their prognostic significance was not determined. In addition, we may suggest that higher MPV and PDW values are new independent risk factors for CVST development.

Keywords: Mean platelet volüme, Platelet distribution width, platelet / lymphocyte ratio, cerebral venous thrombosis

\section{ÖZET}

Amaç: Ortalama platelet hacmi (OPH) ve platelet dağılım genişliği (PDG), platelet hacmini gösteren parametrelerdir. Büyük plateletlerin küçük plateletlere kıyasla enzimatik ve metabolik olarak daha aktif kabul edilmektedir. Artmış OPH ve PDG değerleri ile arteryel tromboz arasındaki ilişki gösterilmiştir ancak venöz trombozdaki yeri tam olarak bilinmemektedir. İnflamatuar bir gösterge kabul edilen platelet/ lenfosit oranının artışının(PLO) birçok hastalıkla ilişkisi bilinmekteyken venöz trombozda kullanımı ile ilgili az sayıda çalışma mevcuttur. Bu nedenle bu çalışmamızdaki amacımız OPH, PDG ve PLO değerleri ile serebral venöz sinüs trombozu(SVST) arasındaki ilişkiyi ortaya koymaktır. Yöntem: Çalışmamıza retrospektif olarak Ocak 2008- Eylül 2016 tarihleri arasında kliniğimizde SVST tanısı ile izlenmiş 54 hasta ile benzer yaş ve cinsiyete sahip 50 kontrol dahil edildi. Hasta ve kontrol grubu OPH, PDG ve PLO değerleri açısından kıyaslandı. Bunun yanında hasta grubu kendi içinde beyin parankimal lezyonu olan ve olmayanlar olarak ikiye ayrılarak OPH, PDG ve PLO’nun prognoz üzerindeki etkisi de değerlendirildi. 
Bulgular: Hasta grubunda kontrollere kıyasla OPH, PDG ve PLO değerleri daha yüksekken parankimal lezyonu olan ve olmayan hastalar arasında anlamlı fark saptanmadı. Ek olarak SVST gelișimi için OPH ve PDG değerleri anlamlı bağımsız değişkenler olarak saptanırken ROC analizi ile optimum cut-off değerleri OPH için 8.85 iken, PDG için 15.75, PLO için ise 168.53 olarak tespit edildi.

Sonuç: Sonuç olarak, OPH, PDG ve PLO değerleri SVST'li hastalarda kontrollerden daha yüksek bulunmuştur ancak prognozu belirlemede etkileri saptanmamıştır. Ek olarak, OPH ile PDG yüksekliğinin SVST gelişimi için yeni bir bağımsız risk faktörleri olduğunu söyleyebiliriz.

Anahtar sözcükler: Ortalama platelet hacmi, platelet dağılım genişliği, platelet/lenfosit oranı, serebral venöz tromboz

\section{INTRODUCTION}

Cerebral venous sinus thrombosis (CVST) is a neurological condition that is rarer than the arterial occlusive diseases of the brain but highly serious which may affect all age groups, while it is seen more frequently in young adults ${ }^{1}$. Clinical signs are highly variable and dependent on the severity of clinical results, the magnitude of the thrombotic process, its localization and severity. Poor prognostic factors are old age and complications such as involvement of cortical and deep cerebral venous systems, increased intracranial pressure, loss of consciousness and accompanied parenchymal lesion, as well as pulmonary embolism ${ }^{1,2}$.

It is known that the development process of venous thrombosis is different to that or arterial thrombosis, but it has not been completely understood yet. Thrombosis starts with the aggregation of erythrocytes, fibrins and platelets ${ }^{3,4}$. Platelets produce proinflammatory molecules that have prothrombic activity and this causes thrombosis to develop and progress ${ }^{5}$. It is assumed that large platelets are enzymatically and metabolically more active than small platelets. Mean platelet volume (MPV) and platelet distribution width (PDW) are parameters that indicate platelet volume. While it is thought that increase in MPV and PDW is related to vascular diseases, acute myocardial infarction and hypercholesteremia ${ }^{6-11}$, there is a limited number of studies in the literature about the relationship of MPV and PDW with venous thrombosis and especially CVST. While increased platelet/ lymphocyte ratio (PLR) is accepted as both a risk factor and a prognostic factor in various diseases, its place in venous thrombosis is not completely known. Thus, in our study, we investigated the role of MPV, PDW and PLR values in CVST and the severity of the disease by retrospectively analyzing MPV, PDW and PLR values in acute period CVST patients.

\section{MATERIAL AND METHODS Sample:}

Our study included CVST-diagnosed 54 patients who applied to the Cumhuriyet University Hospital Neurology Department between January 2008 and September 2016, and who were diagnoses were final. Diagnosis of the CVST diagnosis was based on the patient's history, neurological examination findings, and demonstration of the occult venous sinus via cranial magnetic resonance imaging (cMRI), MRI venography or digital subtraction angiography (DSA). Exclusion criteria of the study were being under the age of 18 , history of ischemic stroke, peripheral vascular disease, pulmonary embolism, infection, acute myocardial infarction, and usage of antiaggregant, anticoagulant or lipid lowering medicine. In the both of the groups routine hematologic and biochemical tests including glucose, blood urea nitrogen (BUN), creatinine, liver function tests, electrolytes and thyroid function tests were examined. Additionally, in the patient group, antinuclear antibody, anti-double-stranded DNA, lupus anticoagulant, antiphospholipid antibodies, protein $\mathrm{C}$ and S, antithrombin III and factor V Leiden mutation were also investigated. The control group consisted of 50 age- and sex- matched volunteers who did not have any systemic disease and provided blood samples for any reason other than CVST.

\section{Analysis of the Blood Samples:}

The blood samples of all patients included in the study were collected in the first 24 hours of hospitalization from the antecubital vein. Complete blood counts were made with Diagon kit on Mindray BC-6800 device and MPV and PDW values and platelet and lymphocyte counts were obtained from this device. PLR values were determined by dividing the platelet count by the lymphocyte count. The glucose, creatinine and BUN measurements were analyzed in a fully automated way with the nephelometric method using a Beckman Coulter AU5800 device. 


\section{Statistical Analysis:}

The SPSS (Ver: 22.0) software was used for the statistical analysis of our data. The data were analyzed using descriptive techniques (mean and standard deviation). Additionally, in the analyses of the data, analysis of variance was used when parametric test assumptions were complied with (Kolmogorov-Smirnov), and Bonferroni, MannWhitney $\mathrm{U}$ and Chi-Squared tests were used when they were not. Categorical data were presented as numbers and percentages. Receiver operating characteristic curve (ROC) analysis was used to determine the optimum cut-off MPV, PDW and PLR values which are risk factors for CVST development. In order to determine the independent variables in development of CVST, logistic regression analysis was used. A value of $\mathrm{p}<0.05$ was accepted as statistically significant.

\section{RESULTS}

While there was no statistically significant difference between the patient and control groups in terms of age and sex $(\mathrm{p}=0.07, \mathrm{p}=0.91)$; glucose was found higher in the patient group $(\mathrm{p}=0.01)$, and creatinine was found higher in the control group $(\mathrm{p}=0.03)$, and there was no significant different in terms of BUN ( $\mathrm{p}=0.09)$ (Table 1). 52 of the patients were diagnosed by MRI and MRI venography, and two were diagnosed by DSA. While the most frequently detected symptom in the patient group was headache $(74.1 \%)$, the most frequent sign was papilledema (85.2\%) (Table 2). The most frequently involved sinuses were the sagittal sinus and the transverse sinus (Table 3). Among the etiologic reasons, the most frequently encountered was postpartum state $(18.5 \%)$, while no etiologic reasons were found in 26 patients (Table 4).

Table 1. The baseline demographic, clinical, and laboratory characteristics of the control and the patient groups. Abbreviations: CVST: cerebral venous sinus thrombosis; DM: diabetes mellitus; Hb: hemoglobin; HT: hypertension; MPV: mean platelet volume; L(+):patients with parenchymal lesion; L(-):patients without parenchymal lesion; PDW: platelet distribution width; PLR: platelet to lymphocyte ratio; SD: standard deviation; WBC: white blood cell.

\begin{tabular}{|c|c|c|c|c|c|}
\hline & $\begin{array}{c}\text { Control Group } \\
(\mathbf{n}=50)\end{array}$ & \multicolumn{2}{|c|}{$\begin{array}{c}\text { CVST Group } \\
(\mathrm{n}=54)\end{array}$} & $X^{2}$ value & p values \\
\hline Male, $n(\%)$ & $21(38.9 \%)$ & \multicolumn{2}{|c|}{$20(40 \%)$} & 0.01 & 0.91 \\
\hline HT Presence, n(\%) & $15(30 \%)$ & \multicolumn{2}{|c|}{$16(29.6 \%)$} & 1.76 & 0.91 \\
\hline DM Presence, n(\%) & $10(20 \%)$ & \multicolumn{2}{|c|}{$11(20.4 \%)$} & 2.21 & 0.97 \\
\hline Smoking, n(\%) & $25(50 \%)$ & \multicolumn{2}{|c|}{$28(52 \%)$} & 3.35 & 0.62 \\
\hline $\begin{array}{l}\text { Age }(\text { mean } \pm \text { SD) } \\
(\min -\max )\end{array}$ & $\begin{array}{l}45.80 \pm 12.52 \\
(23-73)\end{array}$ & \multicolumn{2}{|c|}{$\begin{array}{c}40.87 \pm 14.63 \\
(24-77)\end{array}$} & & 0.07 \\
\hline $\begin{array}{l}\mathrm{BUN}(\mathbf{m g} / \mathbf{d L})(\operatorname{mean} \pm \mathrm{SD}) \\
(\min -m a x)\end{array}$ & $\begin{array}{c}14.26 \pm 5.01 \\
(6.5-33) \\
\end{array}$ & \multicolumn{2}{|c|}{$\begin{array}{c}12.80 \pm 5.28 \\
(3.8-35)\end{array}$} & & 0.09 \\
\hline $\begin{array}{l}\text { Creatine(mgr/dL) (mean } \pm \\
\text { SD) } \\
\text { (min-max) }\end{array}$ & $\begin{array}{l}0.80 \pm 0.12 \\
(0.56-1.2)\end{array}$ & \multicolumn{2}{|c|}{$\begin{array}{l}0.78 \pm 0.12 \\
(0.56-1.2)\end{array}$} & & 0.03 \\
\hline $\begin{array}{l}\text { Glucose(mg/dL) (mean } \pm \\
\text { SD) } \\
\text { (min-max) }\end{array}$ & $\begin{array}{c}98.94 \pm 24.32 \\
(68-195)\end{array}$ & \multicolumn{2}{|c|}{$\begin{array}{c}113.59 \pm 37.95 \\
(73-267)\end{array}$} & & 0.01 \\
\hline $\begin{array}{l}\mathrm{Hb}(\mathrm{g} / \mathrm{dL})(\operatorname{mean} \pm \mathrm{SD}) \\
(\text { min-max })\end{array}$ & $\begin{array}{c}14.32 \pm 1.28 \\
(10.2-17.7) \\
\end{array}$ & \multicolumn{2}{|c|}{$\begin{array}{c}14.18 \pm 1.89 \\
(7.8-19)\end{array}$} & & 0.59 \\
\hline $\begin{array}{l}\mathrm{WBC} \times 10^{9} / \mu \mathrm{l}(\operatorname{mean} \pm \mathrm{SD}) \\
(\min -\max )\end{array}$ & $\begin{array}{c}6937.26 \pm 1935.20 \\
(600-12200) \\
\end{array}$ & \multicolumn{2}{|c|}{$\begin{array}{c}7370.82 \pm 1708.10 \\
(700-14000)\end{array}$} & & 0.55 \\
\hline & & $\mathbf{L}(+)$ & $\mathbf{L}(-)$ & & \\
\hline $\begin{array}{l}\operatorname{MPV}(\mathbf{f L})(\operatorname{mean} \pm \mathrm{SD}) \\
(\min -\mathbf{m a x})\end{array}$ & $\begin{array}{l}8.59 \pm 1.01 \\
(7.2-12.0)\end{array}$ & $\begin{array}{c}9.48 \pm 1.16 \\
(7-12.1)\end{array}$ & $\begin{array}{l}9.70 \pm 1.12 \\
(7.0-12.1)\end{array}$ & & $<0.001$ \\
\hline $\begin{array}{l}\operatorname{PDW}(\%)(\operatorname{mean} \pm \mathrm{SD}) \\
(\min -m a x)\end{array}$ & $\begin{array}{l}15.60 \pm 0.68 \\
(12.5-16.6)\end{array}$ & $\begin{array}{c}28.77 \pm 15.49 \\
(15.5-60.7)\end{array}$ & $\begin{array}{c}26.50 \pm 15.11 \\
(15.5-58.2)\end{array}$ & & $<0.001$ \\
\hline $\begin{array}{l}\text { Platelet } \times 10^{3} / \mathrm{L}(\text { mean } \pm \mathrm{SD}) \\
(\text { min-max })\end{array}$ & $\begin{array}{l}222.80 \pm 49.39 \\
(140-323)\end{array}$ & $\begin{array}{l}265.60 \pm 63.36 \\
(164-426)\end{array}$ & $\begin{array}{c}313.27 \pm 118.83 \\
(207-662)\end{array}$ & & $<0.001$ \\
\hline $\begin{array}{l}\text { Lymphocyte } \times 10^{3} / \mu \mathrm{l}(\text { mean } \\
\pm \mathrm{SD}) \\
(\min -\max )\end{array}$ & $\begin{array}{c}1.80 \pm 0.52 \\
(0.60-2.90)\end{array}$ & $\begin{array}{c}1.62 \pm 0.62 \\
(0.60-2.90)\end{array}$ & $\begin{array}{c}1.73 \pm 0.69 \\
(0.60-2.80)\end{array}$ & & 0.473 \\
\hline $\begin{array}{l}\operatorname{PLR}(\operatorname{mean} \\
(\min -\max )\end{array}$ & $\begin{array}{c}135.95 \pm 53.13 \\
(63.52-264.25)\end{array}$ & $\begin{array}{l}196.12 \pm 108.43 \\
(92.35-431.12)\end{array}$ & $\begin{array}{l}212.31 \pm 116.64 \\
(83.12-502.23)\end{array}$ & & 0.004 \\
\hline
\end{tabular}


Table 2. Clinical features of patient group.

\begin{tabular}{|l|r|r|}
\hline Clinical Features & Number of Patients(n) & Percentage \\
\hline Headache & 40 & $74.1 \%$ \\
\hline Hemiparesis/hemihypoesthesia & 24 & $44.4 \%$ \\
\hline Epileptic seizure & 25 & $46.3 \%$ \\
\hline Papilloedema & 46 & $85.2 \%$ \\
\hline Consciousness loss & 12 & $22.2 \%$ \\
\hline
\end{tabular}

Table 3. Involved sinuses in patient group.

\begin{tabular}{|l|r|r|}
\hline Involved Sinuses & Number of Patients(n) & Percentage \\
\hline Superior Sagittal Sinus & 30 & $55.6 \%$ \\
\hline Transverse Sinus & 39 & $72.2 \%$ \\
\hline Sigmoid Sinus & 25 & $46.3 \%$ \\
\hline Cortical Vein & 11 & $20.4 \%$ \\
\hline Cavernous Sinus & 0 & $0 \%$ \\
\hline Jugular Vein & 2 & $3.7 \%$ \\
\hline
\end{tabular}

Table 4. Etiologic factors in patient group.

\begin{tabular}{|l|r|r|}
\hline Etiologic factors & Number of Patients(n) & Percentage \\
\hline Pregnancy & 1 & $1.9 \%$ \\
\hline Spinal Anesthesia & 8 & $14.8 \%$ \\
\hline Pregnancy+ Sppinal Anesthesia & 1 & $1.9 \%$ \\
\hline Postpartum & 10 & $18.5 \%$ \\
\hline Behçet Disease & 2 & $3.7 \%$ \\
\hline Oral Contraceptive Drug Use & 5 & $9.3 \%$ \\
\hline Hypercoagulopathy & 2 & $3.7 \%$ \\
\hline Unidentified & 24 & $44.4 \%$ \\
\hline
\end{tabular}

According to the results of the logistic regression analyses in the patient group, high values of MPV and PDW and high number of platelets was found as independent variables for CVST development (Table 5).

Table 5. Logistic regression analysis of independent significant variables in CVST. Abbreviations: CI: confidence interval; MPV: mean platelet volume; PDW: platelet distribution width; SE: standard error; ß: regression coefficient

\begin{tabular}{|l|r|r|r|r|r|}
\hline & & & & \multicolumn{1}{l|}{ 95\% C.I.for } \\
& B & S.E. & Sig. & \multicolumn{1}{|c|}{$\operatorname{Exp}(\mathbf{B})$} & \multicolumn{1}{|c|}{$\operatorname{EXP(B)}$} \\
\hline MPV & 0.94 & 0.40 & 0.02 & 2.54 & $1.17-5.53$ \\
\hline PDW & 1.35 & 0.83 & 0.10 & 3.85 & $0.76-19.42$ \\
\hline Constant & 0.02 & 0.01 & 0.01 & 1.02 & $1.01-1.03$ \\
\hline
\end{tabular}

Furthermore, in the receiver operating characteristic curve (ROC) analysis, the optimum cut-off values for CVST development were found as 8.85 for MPV (area under the curve (AUC): 0.73, 95\% CI:0.64-0.83, sensitivity:78\%, specificity:52\%) (Figure 1), 15.75 for PDW (AUC:0.82, 95\% CI:0.75-0.90, sensitivity:85\%, specificity:90\%) (Figure 2), and 168.53 for PLR (AUC:0.69, 95\% CI:0.59-0.79, sensitivity:80\%, specificity:48\%) (Figure 3). 
ROC Curve

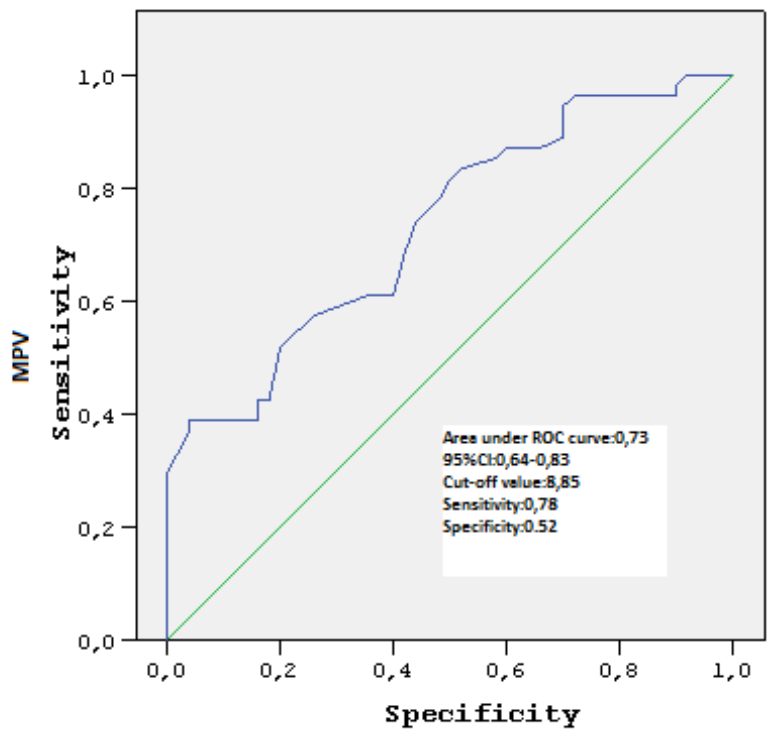

Figure 1. Receiver operating characteristic curve of MPV and CVST ROC Curve

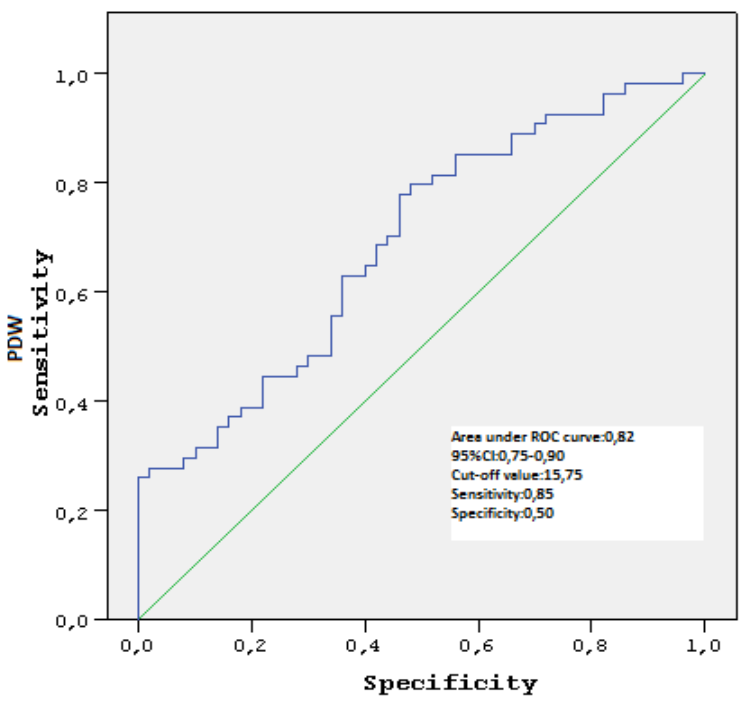

Figure 2. Receiver operating characteristic curve of PDW and CVST 


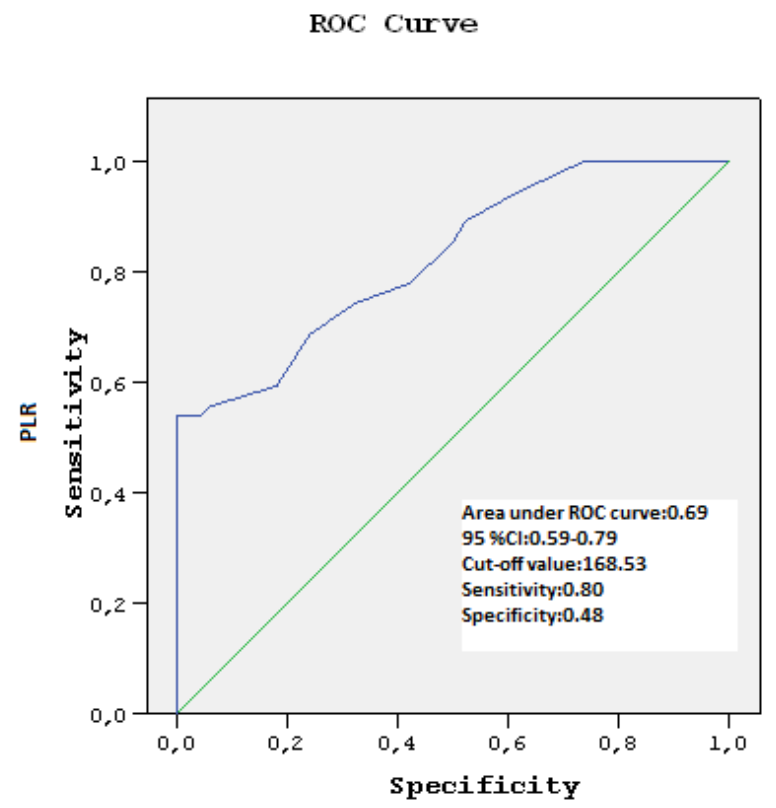

Figure 3. Receiver operating characteristic curve of PLR and CVST

The patient group was then divided into two subgroups based on whether there is a presence of parenchymal lesion or not. While there were parenchymal lesions in 25 patients (46.3\%), there were not in 29 patients. Table 1 shows the MPV, PDW and PLR values, and the comparison of the numbers of platelets and lymphocytes among 3 groups. Accordingly, while the difference among the 3 groups was found significant in terms of MPV, PDW and PLR values $(p<0.05)$, these were found significantly higher in comparison to the control group in both the sub-group with parenchymal lesions and the sub-group without; however, there was no significant difference between the groups with and without parenchymal lesions.

\section{DISCUSSION}

In this study, we showed that MPV, PDW and PLR values in acute period CVST patients are significantly higher than those in healthy adults in the same age group, and high MPV and PDW values are independent risk factors in CVST development.

The development process of venous thrombosis is different to that of arterial thrombosis, and it has not been completely understood yet ${ }^{12}$. The Virchow triad has been used for years to understand the pathophysiology of venous thrombosis ${ }^{3}$. In this triad, it is assumed that changes in blood composition, blood flow or blood vessel walls should be present for venous thrombosis to develop. The most frequently studied one among these 3 is blood composition. It is not yet completely known how stasis in blood flow or changes in blood vessel walls lead to thrombosis ${ }^{3}$. In difference to arterial thrombosis, there is no need for blood vessel wall damage for development of venous thrombosis; however, it is not entirely known what the situation that starts the connection to the normal non-thrombogenic endothelium is. There are two clues about the situation that starts thrombosis: inflammation and stasis. Local inflammation is characterized by the activation of endothelium. Activation of endothelium rapidly leads to secretion of the von Willebrand factor (VWF) and Weibel Palade objects connected to the membrane that contain P-selectin. These two proteins attack the endothelium surface, and thus, thrombosis starts with the aggregation of erythrocytes, fibrins and platelets ${ }^{3,4}$. Platelets produce proinflammatory molecules that have prothrombotic activity, and this situation leads to development and progress of pathological thrombosis via the activated $\mathrm{Gp} 2 \mathrm{~b} / 3 \mathrm{a}^{5}$.

It is assumed that large platelets are more enzymatically and metabolically active than small platelets, and they produce more thromboxane A2 and $\beta$-thromboglobulin ${ }^{12}$. Thromboxane A2 and $\beta$ thromboglobulin have prothrombotic properties and both are related to increased platelet activation. These two molecules increase platelet aggregation and adhesion molecule expression ${ }^{13,14}$. Mean platelet volume (MPV) and platelet distribution width (PDW) are parameters that show platelet volume. Platelet activation leads to morphological changes in platelets such as spherical shape and pseudopod formation. PDW may be used to show these changes. While some studies demonstrated that PDW is a more specific indicator ${ }^{16}, \mathrm{MPV}$ is 
more widely used to measure platelet size ${ }^{13,14}$. Usage of MPV and PDW together may be more effective in prediction of coagulation activation ${ }^{8}$. It was found that MPV and PDW increases are related to vascular diseases, acute myocardial infarction and hypercholesterolemia ${ }^{6-11}$.

The relationship of MPV and PDW with venous thrombosis was rarely studied in the literature. A study found that increased MPV values are an indicator in development of venous thromboses such as deep venous thrombosis and pulmonary embolism ${ }^{16-18}$. In a study by Kamisli et al., it was found that MPV and PDW values in acute period CVST patients were higher than those of controls, and the same values were also higher in patients with parenchymal lesions than those without ${ }^{12}$. Similarly, in our study, MPV and PDW values were found to be higher in the patient group, but no significant difference was found between the patients with parenchymal lesions and the patients without. One of the poor prognostic factors in CVST is the involvement of parenchymal lesions in the brain. Therefore, in difference to the study by Kamisli et al., with the information we have, we cannot state that high MPV and PDW in CVST are related to poor prognosis. However, with the values we have at hand, we may argue that values over 8.85 for MPV and 15.75 for PDW are independent risk factors for CVST development. This may be explained by the relationship of high MPV and PDW values with the prethrombotic state in the acute phase of CVST.

As mentioned above, by producing proinflammatory molecules with prothrombotic activity, platelets lead to both the initiation of thrombosis and the development and progress of pathological thrombosis ${ }^{12}$. The relationship between increased number of platelets and venous thrombosis was demonstrated by various studies ${ }^{18}$, ${ }^{19}$. Additionally, it was accepted that the PLR value obtained by dividing the number of platelets by the number of lymphocytes is an indicator of both inflammatory and thrombotic events 20-22. Moreover, it was shown that high PLR may be used in prediction of prognosis in various oncological, cardiovascular and cerebrovascular diseases ${ }^{22-25}$. The study by Gary et al. also showed that patients with peripheral arterial disease with high PLR values have a tendency for critical extremity ischemia ${ }^{26}$. On the other hand, the relationship between high PLR and venous thrombosis development is much more complex and it has not been completely understood yet. With this purpose, various studies were conducted on development of venous thrombosis in Behçet disease, pulmonary embolism and various oncological diseases ${ }^{27-30}$. In the study by Alan et al., the PLR value was found higher in the group with Behçet disease. While this high value increased along the severity of the disease, there was no difference observed between patients with thrombosis development and those without ${ }^{27}$. Similarly, studies on pulmonary embolism patients showed a linear relationship between PLR values and the severity of the disease, and found it closely related to mortality ${ }^{28-30}$. In addition to these, in the study by Yang et al. on cancer patients, PLR values over 260 were found to be an independent risk factor for development of venous thrombosis ${ }^{22}$. While these studies were conducted, we did not found any study on this issue conducted with CVST patient in the literature. In our study, the mean PLR value was significantly higher in the patient group than in the control group. As in the MPV and PDW values, there was no significant difference between the PLR values in the patient groups with and without parenchymal lesions in the brain. We may additionally assert that a PLR value higher than 168.53 increases development of CVST. This may be the outcome of the role of platelets in the local inflammation that starts venous thrombosis development. Additionally, our results may be explained by PLR values' position as an indicator of both inflammatory and thrombotic events.

One of the main limitations of our study are that other markers that show platelet activation and aggregation were not considered, and the number of patients was low due to the concentric nature of the study. Additionally, our study did not have information about the short- and long-term monitoring and prognosis of the patients. Moreover, while inflammation and thrombosis are continuing processes, our study presents results based on a single measurement.

Consequently, easily computable PLR values and MPV and PDW values that are routinely monitored in almost all laboratories are higher in CVST patients than in healthy controls. Additionally, we may state with these results that high values of MPV and PDW are independent risk factors for development of CVST. More prospective and larger studies on this issue are needed for the future.

\section{REFERENCES}

1. Masuhr F, Mehraein S, Einhaupl K. Cerebral venous and sinus thrombosis. J Neurol. 2004; 251: 11-23.

2. Zubkov AY, McBane RD, Brown RD, Rabinstein AA. Brain lesions in cerebral venous sinus thrombosis. Stroke. 2009; 40: 1509-11. 
3. Lo'pez JA, Chen J. Pathophysiology of venous thrombosis. Thromb Res 2009;123(suppl 4):S30S34.

4. Kuroiwa Y, Yamashita A, Miyati T, et al. MR signal change in venous thrombus relates organizing process and thrombolytic response in rabbit. Magn Reson Imaging 2011; 29: 975-84.

5. Puddu P, Muscari A, Puddu GM, Cravero E, Giannoni C, Zoli M. The complexity of platelet metabolism and its contribution to atherothrombosis. Acta Cardiol 2009; 64: 157-65.

6. Mayda-Domac, F, Misirli H, Yilmaz M. Prognostic role of mean platelet volume and platelet count in ischemic and hemorrhagic stroke. J Stroke Cerebrovasc Dis 2010; 19: 66-72.

7. Vizioli L, Muscari S, Muscari A. The relationship of mean platelet volume with the risk and prognosis of cardiovascular diseases. Int J Clin Pract 2009; 63: 1509-15.

8. Demirtunc R, Duman D, Basar M, Bilgi M, Teomete M, Garip T. The relationship between glycemic control and platelet activity in type 2 diabetes mellitus. J Diabetes Complications 2009; 23: 89-94.

9. Zuberi BF, Akhtar N, Afsar S. Comparison of mean platelet volume in patients with diabetes mellitus, impaired fasting glucose and nondiabetic subjects Singapore Med J 2008; 49: 114-6.

10. Jindal S, Gupta S, Gupta R, et al. Platelet indices in diabetes mellitus: indicators of diabetic microvascular complications. Hematology 2011; 16: 86-9.

11. De Luca G, Venegoni L, Iorio S, et al. Platelet distribution width and the extent of coronary artery disease: results from a large prospective study. Platelets 2010; 21: 508-14.

12. Kamisli O, Kamisli S, Kablan Y, et al. The Prognostic Value of an Increased Mean Platelet Volume and Platelet Distribution Width in the Early Phase of Cerebral Venous Sinus Thrombosis. Clinical and Applied Thrombosis/Hemostasis 2013; 19: 29-32.

13. Ntaios G, Gurer O, Faouzi M, Aubert C, Michel $\mathrm{P}$. Hypertension is an indepedent predictor of mean platelet volume in patients with acute ischemic stroke [published online January 4, 2010]. Intern Med J 2010.

14. Chu SG, Becker RC, Berger PB, et al. Mean platelet volume as a predictor of cardiovascular risk: a systematic review and metaanalysis. J Thromb Haemost. 2010; 8: 148-56.
15. Vagdatli E, Gounari E, Lazaridou E, Katsibourlia E, Tsikopoulou F, Labrianou I. Platelet distribution width: a simple, practical and specific marker of activation of coagulation. Hippokratia 2010; 14: 28-32.

16. Braekkan SK, Mathiesen EB, Njølstad I, Wilsgaard T, Størmer J, Hansen JB. Mean platelet volume is a risk factor for venous thromboembolism: the Tromsø Study, Tromsø, Norway. J Thromb Haemost 2010; 8: 157-62.

17. Gulcan M, Varol E, Etli M, Aksoy F, Kayan M. Mean platelet volume is increased in patients with deep vein thrombosis [published online November 22, 2011]. Clin Appl Thromb Hemost. 2011.

18. Cay N, Ipek A, Gumus M, Birkan Z, Ozmen E. Platelet activity indices in patients with deep vein thrombosis [published online September 23, 2011]. Clin Appl Thromb Hemost. 2011.

19. Simanek R, Vormittag R, Ay C, et al. High platelet count associated with venous thromboembolism in cancer patients: results from the Vienna Cancer and Thrombosis Study (CATS). J Thromb Haemost 2010; 8: 11420.

20. Ishihara $\mathrm{H}$, Kondo $\mathrm{T}$, Yoshida $\mathrm{K}$, et al. Effect of Systemic Inflammation on Survival in Patients With Metastatic Renal Cell Carcinoma Receiving Second-line Molecular-targeted Therapy. Clin Genitourin Cancer 2017 Feb 1. pii: S15587673(17)30034-4. doi:10.1016/j.clgc.2017.01.018. [Epub ahead of print]

21. Bin He C, Lin X.J. Inflammation scores predict the survival of patients with hepatocellular carcinoma who were treated with transarterial chemoembolization and recombinant human type5 adenovirus H101. PLoS One 2017; 12: e0174769.

22. Liu H, Wu Y, Wang Z, Yao Y, Chen F, Zhang $\mathrm{H}$, et al.. Pretreatment platelet-to-lymphocyte ratio (PLR) as a predictor of response to first-line platinum-based chemotherapy and prognosis for patients with non-small cell lung cancer. J Thorac Dis 2013; 5: 783-9.

23. Yang W, Liu Y. Platelet-lymphocyte ratio is a predictor of venous thromboembolism in cancer patients. Thromb Res 2015; 136: 212-5.

24. Ly HQ, Kirtane AJ, Murphy SA et al: Association of platelet counts on presentation and clinical outcomes in ST-elevation myocardial infarction (from the TIMI Trials). Am J Cardiol 2006; 98: 1-5. 
25. Osadnik T, Wasilewski J, Lekston A, et al. The platelet-to-lymphocyte ratio as a predictor of allcause mortality in patients with coronary artery disease undergoing elective percutaneous coronary intervention and stent implantation. J Saudi Heart Assoc 2015; 27: 144-51.

26. Gary T, Pichler M, Belaj K et al: Platelet-tolymphocyte ratio: a novel marker for critical limb ischemia in peripheral arterial occlusive disease patients. PLoS One 2013; 8: 676-88.

27. Alan S, Tuna S, Türkoğlu E.B. The relation of neutrophil-to-lymphocyte ratio, platelet-tolymphocyte ratio, and mean platelet volume with the presence and severity of Behçet's syndrome. Kaohsiung J Med Sci 2015; 31: 626-31.
28. Ozcan Cetin E.H, Cetin MS., Canpolat U, et al. Platelet-to-lymphocyte ratio as a novel marker of in-hospital and long-term adverse outcomes among patients with acute pulmonary embolism: A single center large-scale study. Thrombosis Research 2017; 150: 33-40.

29. Ertem A.G, Yayla C, Acar B. Relation between lymphocyte to monocyte ratio and short-term mortality in patients with acute pulmonary embolism. Clin Resp J 2016; 27: 247-58.

30. Ateş H, Ates I, Kundi H, et al. Diagnostic validity of hematologic parameters in evaluation of massive pulmonary embolism. J Clin Lab Anal 2016 Oct 6. doi:10.1002/jcla.22072. 